\title{
EFFECT OF VITAMIN E AND SELENIUM SUPPLEMENT ON PREGNANT COWS AND THEIR CALVES
}

\author{
F. H., El-Sangary; 1. M., Gamal E1-Din* and M. F., E1-Kabany \\ Depl. of wheminstry. Nulullional drifedencye and toxins \\ Dept. of pathology and clinical patlosjogy*

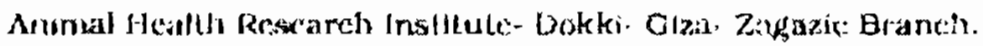

\begin{abstract}
SUMMLARY
The present study was designed to invesrigate the elfect of selerium and or vita mun $E$ on pregnank cows and their calves. Thirty two heolthy pregnant cows were used in this investigation. 7hey urere divlded into four equal groups. The fust group was considtered as control without treatment, the second group was injected intramuscular with selentum as sodtum selenite (5ng/ rookg B.W], the thut group, was adminis

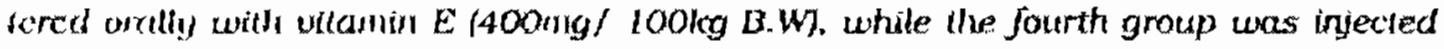
will setenium and administered orally with vitamin $E$ too. One dose weekdy for three stuccessive weeks was used. The blood samples were collected from the pregnant cows and ther neonatal calves for determination the levels of selenium, vitarini $E$. Lotit imnumloglobulins and total proteins. The obtained result reveaded that selenium and/ or vitomin $E$ induced improvement in the frnmune status of the newly bom calves and also, their levels in these calves. It could be concluded that setentum and viturin $E$ have sumergistic effect 50. it is better to give them together to pregnant cows, when used as propilulaxis from diseases caused by ullamin E deficiency,
\end{abstract}

\section{ENTRODUCTION}

Selenium and vitamin $E$ have been recognised for several years as nutrents crttcal for optmal livestuck growth, prodicetivity and health, (Metre et al., 2001). The bloehemical mole of selenium was demonstrated by Rotruch et al. (1973) to be as a component of the enzyme glucalnlone peroxidase, Gluathlone peroxidase functions in celkular oxtdation- reduction rcaetions lo proted the coll frotn oxldative damage from free radicals and peroxldes (Flohe et al., 1973). Vitamlu $\mathrm{E}$ ( $\alpha$ - tocopherol) also functlons as an anuoxidant and protects the cell agalnst oxJdative damage: however, it is lipid soluble and prinarly associated with the ecll unembranes. Thr. complementary lunetions of selenlum and vitamin $E$ have been hypotheslzed. where. supplementa. ivil with one can reduce, but not ellminate the requirement for the othor (Hoekstra. 1975 
Maas. 1983). The aetion of vilamin E and selenlum appear to be synergiste (Frye 1991).

Selenturn and vitanin $E$ also, have important roles in Imnune system funetion and resistance lo discases (Dhur et al. 1999). Whicre the offspring of the natrue breed of cows which suppls; mented with selcuium and vilamin $\mathrm{E}$ (i)uring the prepartum pertod had greater concentration of imnunoglobulíns (Nagura et al., 2000). Newly bom calves take malernal anlitxidies lrom coloatrum during the first 24 hour of life (Selman et al., 1970). Therefore, it is desirable to increase the cow's colostrum antibody contcnt. Cows glven selendum and vitamin E produced more colos(rum. and morc Irumunoglobulins than in unireated cows (Lacetera et al., 1996). Two routes cxist for transfer of selentum from the dam to the calf: placental trambler and mulk. The placental transfer of seleutum has already bcen demonstrated in cattle, because the matemal supplemen tatlon of cows in latc geslation increascs selenlum reserve in the liver of the foetus or new born (Abd el-Rahman and kineald 1996). The amount of selentum consumed by cows durtng the non tactating pertod has been shown to affect selentum concentraton in serum of thetr new born calves. (Awadeh et al., 1998). Whilc vtlamln E crosses the placental bartcr much less readily. so. the newly boin calves have adequate serum selenium level and lower serum a- locopherol Irvols than thelr durns (Scott 1978).

In the present study, selentum and vitamin $\mathbf{E}$ were adrnintstered - alone or in combinatlon- In excess to pregnant cows alming to investigate their influence on their levels In these cows and their neonatal calves until weaning and on the lmmune status of both.

\section{MLATERIALS AND METHODS}

A) Animals: The study was carried out on a farm in Wadl EI-Moolak, Ismalla govemorate. Thic selection of the pregnant cows was depend on the health slatus. They were healthy, without reproductive problems and in the same reproductuve eycle. The cows were free from external and intcrnal parasites. Cows in this farm grazed in berseem pastures (Trifollum alexandrinum $\mathrm{L}$ ) from January to May, whille. from June to December, these antmals were thed in open sheds and fed on ration consist cd of concentrales and ricc straw. Green com (Darawa), when was avallable. was offered to these antmals during this pertod.

Thirty- Two pregnant cows (3-5 years old), In the last month of pregnancy, were divded into tour equal groups of 8 :

1) cows in the first group (gC) served as control and recelved the basle feed. which covers the dietary needs of a pregnant and lactating cow, 


\section{F. H., El-Sangary; et al...}

2) cows in the second group (gSel recejved the bastc iced and additionally inuamuscular sclenium iryection of 5nus. selcntum/ Jo0kg B.W. (Fatma 1997).

3) cows in the third group ( $\mathrm{gE}$ ) recefved the above basic feed supplemented with an addlional $400 \mathrm{ng} / 100 \mathrm{k} g \mathrm{~B}$ B.W of vitamin ti as a-tucopberol akstute. (Fatma 1997).

4l cows in the frourth group (gESe) recclved the basir feed plus $400 \mathrm{ng}$ of vilimin $\mathrm{E} / 100 \mathrm{~kg}$ B.W. and fntranuscular selenium injection of $5 \mathrm{ng}$ seccritung/ $100 \mathrm{~kg}$ B.W.

the drugs used as one dlose weekly for three successive wceks before parturation.

B) Drugs: I- selentum; was used in thls study as an aqueous solution of sodium selenite* [2.5mg sclerium/ $1 \mathrm{~m}$ il solution.

2- vitamin E: was obtalned as a viscous oil of vtamin E (Alpha-tocopherol). it is avallable as solt gelaun capsules (400mg)*

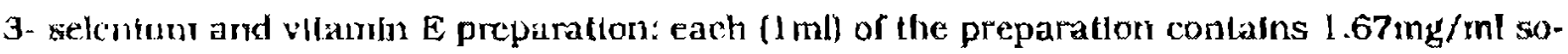
dium setente and $150 \mathrm{mg} / \mathrm{ml}$ vitanun k.

C) Blood samples: The Gist sample was eollected (4 wheks belore parturation) from cows on the starting day of the experinent, before the supplyting with $\infty$-tocopherol and before the selerifurn injeetlon. A second sample was taken on the first day of partiuration. Whille blood samples from newly born calves were eallected, ut 36 hrs. of age, and from the same catves on weantng day.

D) Blochemleal atudies: Sera were separated from the blood clot by centrifugation and used for sclentum, $\infty_{-}$tocopherol, total protein and total tmumumaglobulins deterninaturn.

Scrum selenfum was detcrmined by atomic absorptan spectrophotometer as described by Meret and Henkin (1971)* $\infty$ - Locopherol concentration was deternulned by the method af Oser (1879)**. Total Serum proteins was cstimatcd by the method descrbed by Menry (1908) and total serum immunoglabultns detemmed by the sod. sulphite turbidity test according to stone and Gltter (1969) by using spectrophotometer as adopted by Khall (1975). The data obtained were statistleally analyzed using T.test aecording to Tambane and Dunlop. (2000). 


\section{RESULTS}

1) Determination of selenium in sera of cowg:

Ther rusults of sticnium determination in the seram samples of cows are presented in table (1). On the starting of the experment and before $\alpha$-tocopherol and selentun admulstration, no stalistically significant differences of selentum concentratton were noticed animig the cows of all groips. On fartowing day. cows in the second and fourth groups that were injected will sxicnium (gSe and gESe) had signfleant horease $\left(P_{2} 0.01\right)$ of selcniun levels in thetr sera compared with the control group (gC).

\section{2) Determlnation of selenlum in gera of calves:}

Selenium concentratuon in the representatve calves sera are shown in table (1). Calves In the second and fourth groups In]ceted with selentum (gSe and gESe) had signiffcantly increased levels (Ps 0.05 Ps0.01) comparing with the contral group ( $\mathrm{gC}$ ). elther 36 hrs after birth or at the werishrug dhy.

\section{3) Determinatlon of $\alpha$-tocopherol la mera of cow/s:}

The results or $\alpha$ - tocopherol determination in sera of cows are given in table (2). Serum atoeoherol concentratton did not differ signiflcantly from the control group.

\section{4) Determination of $\alpha$ - tocopheral in ecra of calves:}

The results of the representative ealves serum are shown th table (2). 36 hrg. After birth. calves born to eows supplemented with $\alpha$ toeopherol in the Third (gE) \& fourth gmoups (geSe) had signincanuly Increased level (PS $0.01 \& r_{\leq} 0.001$ ) comparng to the control group (gC).

\section{5) Determlnation of total immunoglobullns in sera of cowg:}

The total immunoglobulins concentration in the sera of cows are presented in table (3). On the slarting day, the mean concentration differences among all animals werc not statistically signilicaint. On farrowing day. cows in the control group $(\mathrm{gC})$ had the lowest mean of immunoglobulins valucs. While. cows of the fourth group (gESe) that reccived both $\alpha$ - tocopherol and selenlum had signiflcantly increased levels ( $P \leq 0,01)$ of total immunoglobulins, compared to the foutrol group (gC). 


\section{6) Determlnation of total inumunoglobulins in sera of calves:}

Calves botn to cows of third $(\mathrm{gE})$ and fourth (gESc) groups always had signefleanlly increased

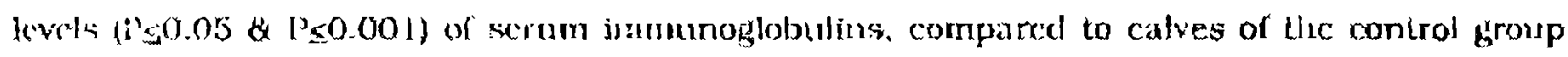
(ge). citser 36 ins. alter birth or at the weanlng day.

7) Determination of serum total proteins in sera of cowe and thelk calves: are uncscited in table (4).

\section{DISCUSSION}

Selcrium is an essential element in the dict of animals and has a vartety of roles; it is an antioxidant that works in conjunction with vitamin $\mathrm{E}$ to prevent and repalr cell damage in the body. is invulved in trmine lunction and is necessary for growth and fertllity. (plant 2003).

The prescut study investigate the effect of administration of selenium and $\alpha$-toeopherol ace-

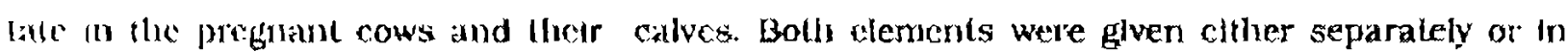
combination.

At the beginning of the experiment (zero time), the mean serum concentration values of sele. illum. a- tocopherol, total proteins. and total immunoglobulins were not signilicantly different among the four groups of coxvs.

The Intra muscular injeetion of selcnfum in pregnant cuws increased the scrum selentum concentration of the cows and calves. Selenium transfer from pregnant cows to thelr embryos was denonstrated in eattle (Abde1-Rahman and Khocald 1095). Therefore. sclenium that was detecied in calves sera 24-36 h. after birth onglnates from placental transfer and from colostruln uptake. This latter linding is in agrement with the observation made by Underwood (1971). that calves absorb selentum from colostrum and nilk, and carry it in blond bound to plasma proleins. Also, Perry et al.,(1978) rccorded that sclenlum level of call serum at birth is a reflecthon of the maternal selenlum supplementatlon. Rock et al., (2001) mentioned that pregnant elw's which fed on additional selenium hat inereased concentratlon of selentum in whole blood and serum.

On the other hand. theer resulte show a significant inerease in total immunoglobulins in selenilum injected cows than non- Injected eontrol ones. These data agree wh the results obtaincot by Fayek et al.. (1089) in sow5, Bednarek et al., (1094) in calves. Mllad and Kovae (1990) in ewes and Hassan et al., (2001) in horses. Similar resulis obtained by Awadeh et al.. (1998) who found that selenium supplementation increasc colostral immunoglobulins concentrations in 
cows and serum !mmunoglobulins concentratons in their calves. Also. Arthur et al., (2003) reported that selentum supplementation increuse the level of serum immunoglobultns and the production of sccondary antibodies to antigen.

On the farrowing day, a decrease ci $\alpha$ - tocopherol was notlced in all cows, in contrast, calves

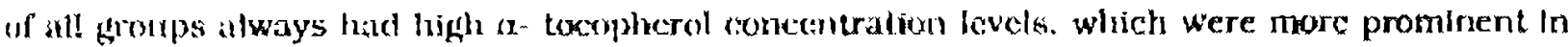
calves from rows of (gE) and (gESe). Thls a- tocophenol was obvously. takcen from colostrum and milk. where. It was uralned Irom plasma. 17ils explains the decreased a- tocopherol concentra. tion in cow's seriun on the lartowng day and conflnns the observations made by Malm et al., (1976) who reported that the $\alpha$ - tocopherol concentration in colostrum could be 6-36 tumes greater in sows which were supplicd with extra $\alpha$ - tocopherol dunng pregnancy.

The combined use of $\alpha$ - tocopheral and selenjum proved to be more beneficlal for cows and calves than thcir separate administration. This agreed with Lacetera et al., (1996) who reported that cows trcatcd with selenlum and $\alpha$-tocopherol acetate 3 weeks before calving had higher glutathlone peroxidase values at calving and durtng the first 12 weeks of lactation. Also. in thelr calves. Uie glutalhione peroxidase values were signilleantly high at birth and 4 weeks of age. Also. Ikewehl et al. (1997) reported that the scrum selcnlum and vitamin E. levels in dams and their calves, fed selenlum \& vitainin $\mathbb{E}$ were signifcantly higher than those in eantrol. On the other hand, our results showed that. thighest Immunoglobulins concentrations was detected In cows that recelved both $\alpha$ - tocopherol and selenjum (geSe). The Influence of extra $\alpha$ - tocopherol and selentum administration to cows was reflected in thetr calves on the farrowing and weanIng days. Where, calves of eows In (gESel group had the highest Immunoglobulins concentration. which was statistleatly significantly different from that in the other groups. Our results agreed wth Megahed and Daghash (1909) who observed inerease of total immunoglobullns concentration in newly born calves after tnjection of vitamin $\mathrm{E}$ and selenlum. In cows during late gestation. This could be attributed to the effect of selenlum and vitamin $E$ whtch increased absorption of globulin and essential proteln digested products which was eventually reflected on the obtalned parameters (Abbas 2002). Also, the present results revealed that the total protein signiflcanty increased in cows whith rccelver both selenlum and $\alpha$ - tocophcrol acetate. and thls Increase, was detecterl in their calves, (Table 4). These results run parallel with those obtained by Fatma (1897) who reported that the increased proteln level of the treated groups can be attributed to the incrcase in globulin level, also. Metry et al., (1898) in calves and lastly shatira \& Mona (2006) in lambs. The sex of calves had no effect on the values of any of the parameters examined. since males and females reacted very sinularly.

In conclusion, this study indicate that selenlum supplementation was less effective than el- 
F. H., Et-Sangary; et al...

ther $\alpha$ - tocopherol supplementation alone or the comblncd supplementation of selentum and $\alpha$ tocopherol. The administrution of cxtra- $\alpha$ - locopheral by the pregnant cows In eombination with the Injcetion of selentum regularly durng pregnancy. proved to be very benefletal for cows and their calves. Where it Improves thedr health status dunng the cruclal pertod of preginancy and weaning. And it is also an Important factor in call Immunlty. So. It is better and advisable to give selentum and vitamin E together to pregnant cows. when used as a mean of prophylaxds from diseascy caused by vitamln E denelency and not selenium alone. 
Table (1): Selenium levels ( $\mu \mathrm{g} / d \mathrm{l})$ in the serum of cons and calves.

\begin{tabular}{|l|c|c|c|c|}
\hline & $\begin{array}{c}G 1 \\
(\mathrm{gC})\end{array}$ & $\begin{array}{c}G 2 \\
(\mathrm{gSe})\end{array}$ & $\begin{array}{c}\mathrm{G3} \\
(\mathrm{gE})\end{array}$ & $\begin{array}{c}G 4 \\
(\mathrm{gESe})\end{array}$ \\
\hline Cows ar lass month of pregnancy & $5.18 \pm 0.21$ & $5.41 \pm 0.33$ & $5.61 \pm 0.18$ & $5.48 \pm 0.37$ \\
\hline Cows on day of tarrowing & $5.22 \pm 0.41$ & $6.81 \pm 0.28^{* *}$ & $5.01 \pm 0.21$ & $6.93 \pm 0.28^{* *}$ \\
\hline Calves 36 hrs posiparturt. & $5.17 \pm 0.13$ & $6.21 \pm 0.22^{\circ *}$ & $5.18 \pm 0.31$ & $6.14 \pm 0.35^{*}$ \\
\hline Calves on weaning day. & $5.15 \pm 0.18$ & $6.31 \pm 0.44^{\circ}$ & $5.11 \pm 0.1$ & $6.33 \pm 0.48^{*}$ \\
\hline
\end{tabular}

Table (2): $\alpha$-rocopherol levels $(\mu \mathrm{g} / d l)$ in the serum of cows and calves.

\begin{tabular}{|l|c|c|c|c|}
\hline & $\begin{array}{c}\mathrm{G} 1 \\
(\mathrm{gC})\end{array}$ & $\begin{array}{c}\mathrm{G} 2 \\
(\mathrm{gSe})\end{array}$ & $\begin{array}{c}\mathrm{G3} \\
(\mathrm{gE})\end{array}$ & $\begin{array}{c}\text { G4 } \\
(\mathrm{gESe})\end{array}$ \\
\hline Cows al last month of pregnancy & $236.7 \pm 5.6$ & $219.6 \pm 6.41$ & $234.22 \pm 4.12$ & $222.34 \pm 7.21$ \\
\hline Cows on day of farrowing & $198.6 \pm 5.15$ & $181.5 \pm 6.28$ & $196.4 \pm 3.81$ & $184.5 \pm 5.31$ \\
\hline Calves 36 lirs. postpartum. & $223.7 \pm 3.41$ & $214.3 \pm 2.81$ & $241.3 \pm 4.72 \cdots 0$ & $254.2 \pm 6.11 \mathrm{**}$ \\
\hline Calves on weaning day. & $211.5 \pm 3.62$ & $201.7 \pm 4.82$ & $212.9 \pm 5.22$ & $216.7 \pm 4.21$ \\
\hline
\end{tabular}


$F, H$, El-Sangary: et al...

Table (3): total inmumoglobulins lcvels (gm/dl) in the serum of cows and calves.

\begin{tabular}{|l|c|c|c|c|}
\hline & $\begin{array}{c}\text { G1 } \\
\text { (gC) }\end{array}$ & $\begin{array}{c}\text { (i2 } \\
\text { gSe) }\end{array}$ & $\begin{array}{c}\text { G3 } \\
\text { (gE) }\end{array}$ & $\begin{array}{c}\text { G4 } \\
\text { (GESe) }\end{array}$ \\
\hline Cows at last month of pregnaney & $2.11 \pm 0.21$ & $2.01 \pm 0.04$ & $2.24 \pm 0.11$ & $2.13 \pm 0.17$ \\
\hline Cours on day of farrowing & $2.14 \pm 0.16$ & $2.71 \pm 0.15$ & $2.31 \pm 0.21$ & $2.91 \pm 0.11^{* *}$ \\
\hline Calves 36 hrs. postpartum. & $2.17 \pm 0.05$ & $2.41 \pm 0.21$ & $2.67 \pm 0.19^{*}$ & $2.89 \pm 0.13^{* * *}$ \\
\hline Calves on weaning day. & $2.00 \pm 0.07$ & $2.29 \pm 0.13$ & $2.58 \pm 0.04^{\circ \cdots}$ & $2.78 \pm 0.17^{* * *}$ \\
\hline
\end{tabular}

Tabla 4) toral protein levels (gnv'dl) in the serum of cows and calves.

\begin{tabular}{|l|c|c|c|c|}
\hline & $\begin{array}{c}\mathrm{G} 1 \\
\mathrm{GC}\end{array}$ & $\begin{array}{c}\mathrm{G} 2 \\
\mathrm{GSe})\end{array}$ & $\begin{array}{c}\mathrm{G} 3 \\
\mathrm{GE})\end{array}$ & $\begin{array}{c}\text { G4 } \\
\text { GESe) }\end{array}$ \\
\hline Cows at last month of pregnancy & $6.24 \pm 0.42$ & $6.21 \pm 0.18$ & $6.43 \pm 0.26$ & $6.35 \pm 0.19$ \\
\hline Cows on day ofarrowing & $6.16 \pm 0.34$ & $6.62 \pm 0.51$ & $7.05 \pm 0.42$ & $7.84 \pm 0.33^{\circ *}$ \\
\hline Calves 36 hrs. postpartum. & $6.13 \pm 0.29$ & $6.48 \pm 0.35$ & $7.21 \pm 0.22^{*}$ & $7.73 \pm 0.41^{* *}$ \\
\hline Calves on weaning day. & $6.11 \pm 0.14$ & $6.58 \pm 0.28$ & $6.86 \pm 0.31^{*}$ & $6.97 \pm 0.21^{\circ *}$ \\
\hline
\end{tabular}

* Significant at $P \leq 0.05$

** Significant at $\mathrm{P} \leq 0.01$

*** Significant at $\mathrm{P} \leq 0.00 \mathrm{i}$ 


\section{REFFERENCES}

Abbas, S. F. (2002) : effect of vitamin E and selentum injection on lamb viablity, growth performance and some blood serum constitucnts in Saldf lambs. Asslut yet. Med. J. : 47 (94) : $129-138$.

Abdel Ralman, M. M., and Klncald RL. (1905): ETfect of sclcnlum supplementatoln of cows ou maternal transfer of sclentum to fetal and newborn calves 3. Dalry Sel. 78: 625 630.

Arthur, J. R., Mckenize, R. C. and Beckedl C. L. (2003): Setcnlum in the immune system. J. Nutr, 139: $1457 \cdot 1459$.

Awadeb, F. T.; Kincald, R. L. and Johnson, K. A. (1908): Effect of level and source of dietary selenium on concentrations of thyroid homoncs and immunoglobulins in beci cows and calves. 3. Anim. Scl. 76: 1204-1215.

Bednarek, D.: Kondrack, M.: B1k, D.: Anke, M. and Melssner, D. (1994) : The 1nlluence of selemun and vitamln $F_{\text {c }}$ on carotene, Vilanin. A and gammaglobulin concentration in calf serum. Mengen and spurendemente. 14. Arebeitstagung. Jena 25-25 November, 109115.

Dhur, A, Galsn. P, Hercberg. S. (1999): Relatlonship between selenlum, Immlunity, and resistanie against infection Comp. Blochom. Physiol, 96c; $271-280$.

Fatma, 8. M. (1997): Effect of sclentum and vitamin E infection on some blood serum constltumis of buffalo ealves. Zag. Vet. 3.25 (3). $147-152$.

F1ohe, 1., Gunzler W. A and schock H. H. (1973): Glutathone peraxdlase: A selenoenzyme FEBS lett. 32:132.

Frye T. M., (1001) : Vitamin deflencles in caltle. Vet. Clin. North. An. Foad Anim. Pract. 7 : $237-279$.

Hassan, H. M.; Nasser, M. H.; Ramadan, A. A.: EL-Sakran, M. N. and Mansonr, U. M. (2001) : Efrect of vitamin $\mathrm{E}$ and selentun as dietary supplement on cellular and humoral Imnune responses in borses. J. Egypt. Vet Med. Assoc ,6 G[4]: 155 - 164.

Hayek, M. G; Mitchell, G. E.; Hermon. R. J. Jr; stathly, T. S.; Cronwell, G. L.; Tucker, R. E. and Barker, K. B. (1889) : Proctne immunoglobulln transfere after prepartum treatment with selenlum or vilaniln E. 3. Arulm. Sct., 67: $1299-1306$.

Henry, R. J. (1968) : Clintcal chemistry princlples and techniques, Harpo and Row publishers. New York, P. 185. 
Hoeketra, W.G. (1997) : Biochemical function of selenlum and its relation to vitamin E. Fecd. Pror. 34:2083.

Ikeucb1. T.: katamoto, H.; Tomita, K.; Nakaya, I. And Tortkat, Y. (1997): Growth and im-

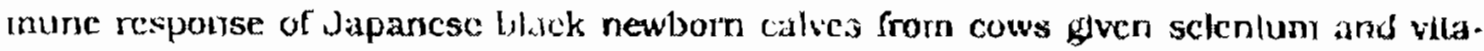
min E during pregnancy. J Japanese Vet. Med. Assoc. 50 (1): $19-23$.

Khalil, A. A (1975): Evaluation of lathoratory methods in the mmunologleal processes af caltie with usage of dufcrent types of pasteurella vaccines Ph. D. Thesis Vet. Fat. Warsa w, Foland.

Lacetera, N.; Berynabucel, U.; Ronchl, B. and Nardone. A. (1896); Eifects of selenlum and vi* lamln $E$ adminlstration durng a late stage of pregnancy on colostrum and milk producLon in dalry cows and on passive inmunity and growth of their offspring. Am. J. Vet. Res. 57 (12): 1776 1780 .

Maas, J. P. (1983) : Diagnosls and inanagement of selentunt- responsive discascs in catlle. Comperu. Contin. Educ. Pratel. Vet. 5:\$393.

Malm, A.; Pond. W.; Walker, E.: Homan, M.; Aydln, G. and Klrtland, D،, (1976) : Elfect of polyunsaturated fatty acids and sttamin $E$ level of the sow gestation dict on reproduction performance and on lcvel of a locopherol in colostrum. milk and dam progeny bloed scrum. J.Anim, Sa1, 42, 393-399.

Megahed, G. A. and Daghash, H. A. (1899) : Effect of preparation infection of antloxidants (Whtamin $\mathrm{E}$ and selentum) on resumption of postpartum ovarian acdvity and subsequent fertslity of ewes. Alex. J. Vct. Sc1, 15, 4: $839-854$

Meret S. and Henken R. I. [1971) : Simultaneous direct estumation by atomic absorption spectropohatometry of copper. zinc and selentum in serum, urne, and C.S.Ë. Clin chem. 17 (5): $367-373$.

Metre, D. C.; Callan, R. J. and van, M. D. C. (2001): Selenlum and viamin E, veterinary clinics of North America. Food Arimal practlce. $17: 2.372-492$.

Metry, G. H.; Yousbef, R. H, and Khattab, R. M. (1988) : Studies on selenium and or vitamin E administration to Egyption buffalo calves. I. cffect on blood senum selenlum level, daily gairl and some blood consutuents. Egyption J. AnIm. Prod, Suppl. Issue, Dec: 451 - 465

Milad. K. and Kovac, G. (1999) : Effect of Injected wtamln E and selentum In late gestation on chosen scrum constituents of ewes and their lambs. Folia-veternaria, 43;4. 163-167

Nagwa, A. B.; EL-Gaafrawy, A. M.; EL-Banna, M. K. and Jbrakim, I. L. (2000) : Effoct of pre: 
partum vitamin $E$ and selenlum treatment on reproductive performance of balady cows and trmmune activity or thetr oflspring. Vel. Med. J. Giza. 49(4); 599 - 607.

Oner B, L. (1979) : Hawk's physlolngical chemistry 14 th cd. McGraw Hill company Ltd., Iondon.

Perry. T. W.; Peterson R. C.; Griflin, D. D. and Beeson, W. M. (1978) : Relallonship of blood selenium levels of pregnant cows to low dictary lntakes. J Anim. Sel., 46. (2) 562-565

Plant. J. W. (2003) : Selenium deficiency In sheep. Agric. Fac A3, $9: 37$, 2nd Ed. pp. I - 6

Rock. M. J.; Lincaid, R. L. and carstens, G. E. (2001) ; Effect of prenatal source and level of dietary selenfum on passlve immunty and themnometabolism of newbom lambs. Small ruminants Res., 40 (2): 129.138.

Rotruch, J. T. A.L, Pope, H. E. Gantbar, A. Swaneon, D. Hafeman, and w. G. Hoekstra, (1973) : Selentum blochemical role as a component of glutathlone psroxdase, Science 179: 588 .

Scolt, M. L. (1978) : Vitanlin E in: the fat soluble wtaming, Handbook of Lipid Research, $2 \mathrm{Ed}$. Deluci, H.E. plerum press. Now york and London P. 133-210.

Selman, 1. E.; Mctwan, A. D. and Flsher, E. W. (1970) : Serum Immunoglobulin concentrations of calves left with their dans for the flrst tow days of life. J. Comp. Pathol., 80:719. 727 .

Shahira, H. H. and Mona, S, A (2006) : Effect of selenium and vitamin E as antioxidant on growth performance, thyroid lunctlon. hematologlcal and some serum biochemlcal parameters in lursius. Kair El- shelkh Vet. Med. J. 4, 1,727-743

Stone, S. S. and Gitter, M. (1969) : The valldily or the soditum sulphite test for detecting immunoglobulin In calf sera. Br. Vet. J. 125: 68-72.

Tamhane, A C. and Duniop, D. D. (2000) : Stathstics and Data malysis from elementary to Intermedlate. Upper Saddle River. U.S.A.

Underwood, E. J.. (1971) : Selenlum. In: Irace Elements In Human and Animal Nutrition, PP. 323-368. 
F. H. El-Sangary; et at...

\title{
الملنخص العريي
}

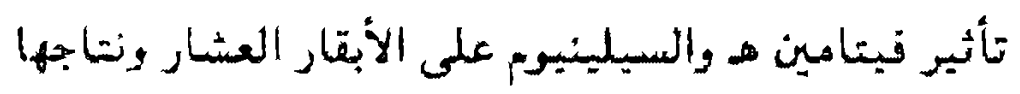

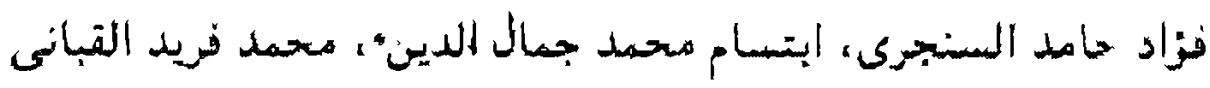

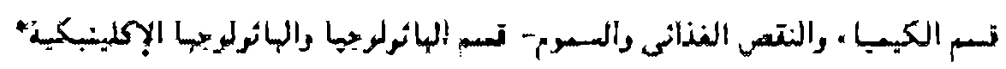

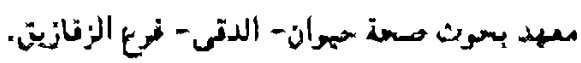

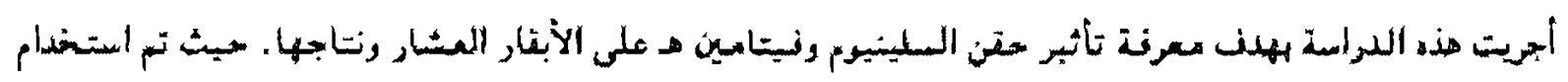

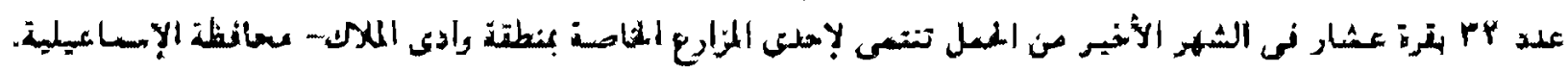

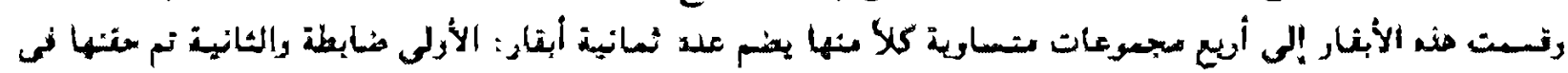

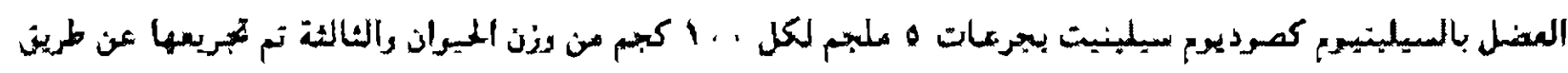

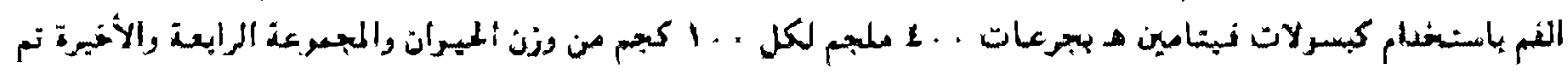

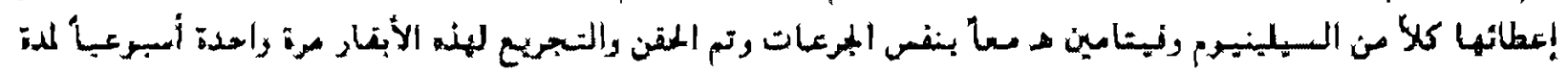

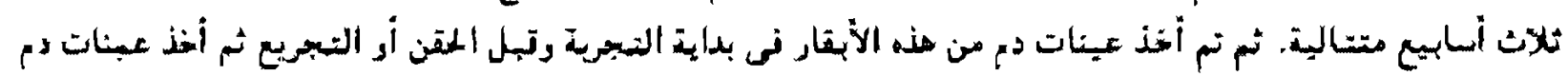

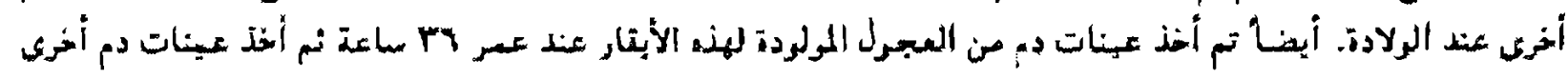

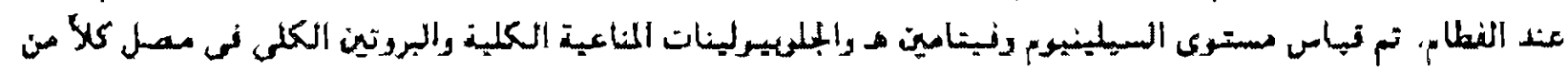

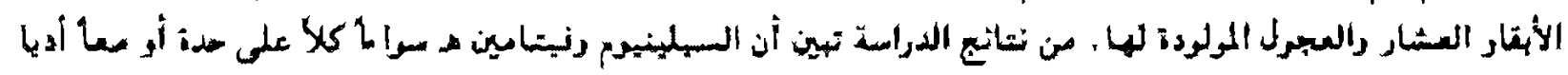

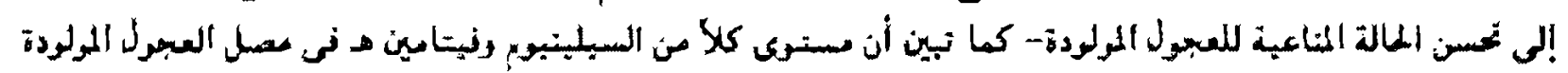

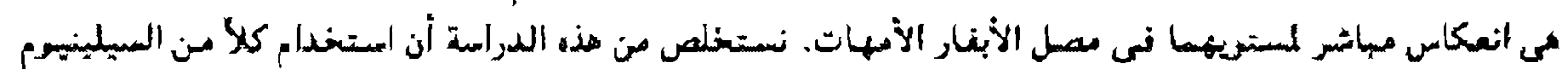

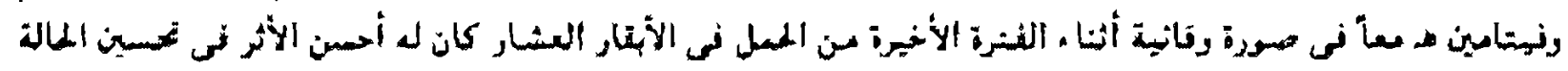

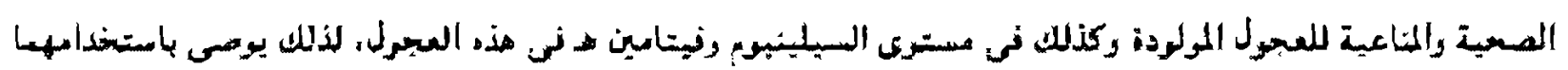

